\title{
BERLIN RADIOCARBON MEASUREMENTS II
}

G. KOHL and H. QUITTA

Deutsche Akademie der Wissenschaften zu Berlin

This date list covers age measurements carried out at the Radiocarbon Dating Laboratory of the German Academy of Sciences of Berlin (DAW) since 1963 and is a continuation of our first date list (Berlin I). Procedures and methods of preparing the samples are essentially the same. We completed our laboratory with a second electronic counting apparatus. Two further proportional counters with internal anticoincidence (Houtermann-Oeschger counters) are made from an old railwaycar axle. The total volume of these counters is $4 \mathrm{~L}$, the effective volume $2.2 \mathrm{~L}$, the background 2.0 counts/min at 700 Torr (acetylene filling), and the contemporary standard value (0.95 NBS oxalic acid) is 20 counts/min. Each sample is measured twice, first for $48 \mathrm{hr}$ and after 8 days for another $24 \mathrm{hr}$. Data have been calculated on the basis of a $\mathrm{C}^{14}$ half-life of $5570 \mathrm{yr}$ (Godwin, 1962). Errors listed include the standard deviations $(1 \sigma)$ of the counting rates of the contemporary samples, the background and the unknown samples. Calculated errors less than 100 yr have been increased to that figure as a minimum.

Corrections have not been made for $\mathrm{C}^{13}$ content. Mass spectrometrics $\mathrm{C}^{13}$ measurements of some samples indicate that errors resulting from fractionation are minimal.

\section{ARCHAEOLOGIC SAMPLES}

The dates published are part of a research program of the Institut für Vor- und Frühgeschichte of the German Academy of Sciences, covering mainly the Neolithic period in Central and South East Europa. In order to help clear up certain chronologic questions, stratigraphically reliable finds were given preference. Cooperation with the Inst. of Archaeol. of the Bulgarian Acad. of Sciences in Sofia for the first time made it possible to date several stages in the East Balkan Karanovo civilization by means of numerous samples from Tell Azmak and Tell Karanovo. It appeared that the vast majority of $\mathrm{C}^{14}$ data agree with those of the relative (stratigraphic) chronology. According to $\mathrm{C}^{14}$ analysis, 18 out of 20 datings of the early Karanovo I/II culture, for instance, are of the first half of the 5th millennium, while the same number of datings of the stratigraphically later Karanovo V and VI stages date back to between 4000 and 3500 B.c.

The first series of measurements of a European Tell settlement is of interest also from the point of view of method. The difference in measured values of samples of the same settlement stratum may be as great as $500 \mathrm{yr}$, so with only few datings there can be no clear temporal differentiation between two successive settlement phases. In a number of cases even greater differences may occur, due to possible contamination and the differing age of timber. Better results may be expected from 
measuring cereals stored in vessels, the age of which usually coincides with the date of the destruction of the settlement.

Considering radiocarbon measurements as well as archaeologic findings (Georgiev, 1961) the South Bulgarian Karanovo I/II culture appears to be a Neolithic civilization probably influenced directly from the Near East. The late Starčevo-Körös civilization, the Sesklo culture in Thessaly, and the Chalcolithic Hacilar I/II and Can Hasan stages in Anatolia developed almost simultaneously. According to $\mathrm{C}^{14}$ data, Karanovo $\mathrm{V}$ and especially VI turn out to be parallel to the beginning of the Vinča-Pločnik stage, the early Gumelnița, Cucuteni and Lengyel civilizations, as well as to the Central European Stroke-ornamented ware (Stichbandkeramik). Therefore the Karanovo III and IV stages, necessarily dating back to the latter half of the 5 th millennium according to stratification, have been identified with the beginning Vinča and Theiss cultures, the Romanian Bojan culture and probably with the early Dimini stages as well. Thus the early dating of the Balkan Ncolithic period so far apparent from a number of isolated $\mathrm{C}^{14}$ dates has been confirmed once more via the Karanovo chronology.

The resulting consequences for the absolute chronology of the Neolithic period in Central Europe can be given only in outline. As far as Linear pottery (Linienbandkeramik), the earliest Neolithic civilization in this area, is concerned we have nearly $40 \mathrm{C}^{14}$ dates of the latter half of the 5th millennium. Although its initial stage is insufficiently dated due to the highly contradictory measurements of ceramic material (Berlin I), we must assume that the beginning of Linear pottery dates back to the time of the late Starčevo-Körös and Karanovo I/II civilizations (Quitta, 1964). By means of radiocarbon measurements the much-debated question of the origin of the spiral meander ornament should be settled too in favor of a Balkan-Anatolian origin. The end of Linear pottery phase and the transition to Stroke-ornamented ware has been fixed by several dates of the early 4th millennium. Some measurements of Berlin, II are single dates, which should not be overrated in their bearing on chronology.

Dates are expressed as before A.D. 1950. Where the archaeologic data are unpublished, we have quoted descriptions and cultural assignments kindly provided by the excavators or their sponsoring institutions. We wish to express our thanks for botanical determinations to Frau Dr. M. Hopf, Römisch-Germanisches Zentralmuseum, Mainz, and also to Herr Dr. K.-D. Jäger, Berlin.

\section{SAMPLE DESCRIPTIONS}

\section{A. German Democratic Republic}

$1360 \pm 100$

Bln-163. Dessau-Mosigkau

Charcoal (Quercus robur L.) from Slavic dwelling site at DessauMosigkau $\left(51^{\circ} 48^{\prime} \mathrm{N}\right.$ Lat, $12^{\circ} 10^{\prime} \mathrm{E}$ Long), Kr. Dessau. Sample from 
wooden rafter in eastern part of Pit-house No. 6, dug to $0.70 \mathrm{~m}$ depth in sand. Assigned to Early Slavic period of 7 th to 8 th century. Excavated 1962 and subm. by B. Krüger, Inst. f. Vor- u. Frühgesch. d. DAW, Berlin (Krüger, 1964). Comment: $\mathrm{C}^{14}$ date of the so-called "Prager Typus" agrees with expected age of immigration of Slavic tribes in Middle Germany.

\section{Bln-353. Dessau-Mosigkau}

$$
1046 \pm 150
$$

Charcoal (Quercus robur L.) from same site of Pit-house No. 16, $0.45 \mathrm{~m}$ depth. Coll. June 14, 1964. Comment: date is much younger than Bln-163; possibly sample was contaminated by recent organic matter.

\section{BIn-251. Dresden-Prohlis}

$7047 \pm 100$

Extracted humic acid from black-brown filling material of a Neolithic building pit in Dresden-Prohlis (51 $1^{\circ} 2^{\prime} \mathrm{N}$ Lat, $13^{\circ} 49^{\prime} \mathrm{E}$ Long). Soil sample taken from Pit No. 4, sunk to $0.70 \mathrm{~m}$ below old surface and covered in post-medieval time by slope loam, $1 \mathrm{~m}$ thick. Pit filling contained potsherds belongs to old phase of Stichbandkeramik (Baumann, Czerney, and Fiedler, 1964). Coll. and subm. by W. Baumann, Landesmus. f. Vorgesch., Dresden. Comment: in contradiction to another dates of Stichbandkeramik, Bln-251 shows relatively high age, possibly because of admixture of humic matter from an older soil. Extraction was made by Institut für Bodenkunde d.Technischen Univ., Dresden by HCl treatment followed by $1 \% \mathrm{NaOH}$. Sample contained $8.8 \%$ carbon.

\section{Bln-248. Helmsdorf}

$3613 \pm 160$

Wood (Quercus sessiliflora Smith) from "prince-burial" at Helmsdorf, locality Heiligenthal $\left(51^{\circ} 36^{\prime} \mathrm{N}\right.$ Lat, $11^{\circ} 38^{\prime} \mathrm{E}$ Long), Kr. Hettstedt. Sample from wooden deathbed (Totenbett), situated ca. $5.50 \mathrm{~m}$ below tumulus surface, inside the wooden tomb. Belongs to late phase of Aunjetitz culture. Exacavated 1906 by H. Grössler, Mus. Eisleben; subm. 1963 by H. Behrens, Landesmus. f. Vorgesch., Halle (Grössler, 1907). Comment: agrees with expected age.

\section{Bln-231. Kmehlen$$
5360 \pm 160
$$ \\ Grain (Triticum dicoccum Schübl, Triticum compactum B.c.} from Neolithic settlement from Neolithic settlement at Kmehlen (51 ${ }^{\circ} 23^{\prime} \mathrm{N}$ Lat, $13^{\circ} 44^{\prime} \mathrm{E}$ Long), Kr. Grossenhain. From cylindrical storage-pit (32.50 m E/2.0 m S), sunk to $0.80 \mathrm{~m}$ depth in yellow loess loam. Although pit is situated inside a Linear pottery house, sherds in pit belong to very early phase of FunnelBeaker culture (Baalberg-Gatersleben group?); one sherd is stroke-ornamented and influenced from late Stichbandkeramik. Excavated Nov. 1963 (continued March 1966) and subm. by W. Baumann, Landesmus. f. Vor-u. Frühgesch., Dresden (Baumann, 1965). Comment: date is impor- 
tant, because transition from early to middle Neolithic is dated for the first time in Central Germany.

\section{Bln-250. Köttichau}

$6045 \pm 120$

4095 B.C.

Extracted humic acid from A-horizon of chernozem soil below Neolithic barrow near Köttichau ( $51^{\circ} 8^{\prime} \mathrm{N}$ Lat, $12^{\circ} 8^{\prime} \mathrm{E}$ Long), Kr. Hohenmölsen. Soil sample was taken in center of the 3-m-high mound, 30 to $50 \mathrm{~cm}$ below upper boundary of old A-horizon (old Neolithic surface). Stratigraphic relations show chernozem is older than the burial belonging to the Salzmünder group of Funnel-Beaker culture. Coll. 1962 by G. Billig, Halle; subm. by W. Baumann (Billig, 1962). Comment: agrees with supposed age of fossil chernozem. Extraction was carried out as for Bln-251. Sample contained $11.4 \%$ carbon (Czerney, 1965).

\section{Bln-398. Ichtershausen}

$2860 \pm 120$

ticum dicoccum) from Bronze-age settlement near Ichtershausen $\left(50^{\circ}\right.$ $52^{\prime} \mathrm{N}$ Lat, $10^{\circ} 58^{\prime} \mathrm{E}$ Long), Kr. Arnstadt. From lower part of Storage-pit No. 11, dug to $0.35 \mathrm{~m}$ in loess loam. Assigned to late "Urnenfelderkultur" (probably "Unstrutgruppe") on basis of other settlement finds. Coll. 1962 and subm. by R. Feustel, Mus. f. Ur- u. Frühgesch. Thüringens, Weimar (Feustel and Gall, 1965). Comment: date agrees with supposed age of settlement.

\section{Bln-220. Königsee-Garsitz}

$13,700 \pm 380$ 11,750 B.c.

Soil sample with bone-charcoal from cave "Bärenkeller" near Königsee-Garsitz $\left(50^{\circ} 58^{\prime} \mathrm{N}\right.$ Lat, $11^{\circ} 5^{\prime} \mathrm{E}$ Long), Kr. Rudolstadt. Found in a fireplace, ca. $20 \mathrm{~m}$ from entrance of cave. Suggested assignment to Gravettian or early Magdelénian. Coll. and subm. by R. Feustel. Comment: on typological evidence Feustel considers Bärenkeller to be earlier (beginning of Würm III Stadial) than $\mathrm{C}^{14}$ date. Possibly sample was contaminated by organic matter of Neolithic and Bronze-age levels above fireplace.

\section{Bln-166. Forst Leina}

$$
\begin{aligned}
& 3830 \pm 100 \\
& 1880 \text { B.c. }
\end{aligned}
$$

Charcoal (Quercus sessiliflora) from Barrow III in Forst Leina, SE of Altenburg $\left(50^{\circ} 58^{\prime} \mathrm{N}\right.$ Lat, $12^{\circ} 31^{\prime} \mathrm{E}$ Long), Kr. Altenburg. Sample was taken $0.90 \mathrm{~m}$ below surface from burnt plankwall, bordering Burial E. Belongs to "Ostsaalische Gruppe" of younger central German Corded ware. Coll. 1962 and subm.. by V. Weber, Landesmus. f. Vorgesch., Dresden (Weber, 1964). Comment: date agrees with numerous $\mathbf{C}^{14}$ measurements of Corded ware.

\section{Bln-225. Radibor-Brohna}

$2063 \pm 100$ 113 B.c.

Charcoal (Quercus sessiliflora) from Slavic fortification at RadiborBrohna (51 $15^{\prime} \mathrm{N}$ Lat, $14^{\circ} 24^{\prime} \mathrm{E}$ Long), Kr. Bautzen. From burned 
layer inside of wall (Point A III, Planum 8). Suggested assignment to Middle Slavic period (10th to 1lth century). Coll. 1951 and subm. by W. Coblenz, Landesmus. f. Vorgesch., Dresden (Coblenz, 1951). Comment: date is much older than expected. As Slavic town wall was set up in a settlement of late Hallstatt period (Billendorfer group), it is possible that charcoal was re-buried.

\section{Bln-176. Rehmsdorf}

$5932 \pm 100$ 3982 B.C.

Wood (Quercus sp.) from stake construction of quadrangular timbered well at Rehmsdorf $\left(51^{\circ} 2^{\prime} \mathrm{N}\right.$ Lat, $12^{\circ} 7^{\prime} \mathrm{W}$ Long), Kr. Zeitz. Sample represents inmost part of round wooden stake of $18 \mathrm{~cm}$ diam. Well was sunk to 5 to $6 \mathrm{~m}$ depth in a browncoal seam and was filled with sandy loam. Dated by pottery on bottom of well to late phase of Linear pottery (S̆arka Typ). Coll. 1921 by E. Amende; subm. by $\mathrm{H}$. Höckner, Mus. Altenburg (Amende, 1928). Comment: agrees with measurements of same Linear pottery phase from Dresden-Nickern (Bln-73: $5955 \pm 100$, Berlin I).

\section{Bln-212. Reitzenhain}

$1024 \pm 160$

Wood (Betula sp.) of a yoke from peatbog near Reitzenhain $\left(50^{\circ}\right.$ $33^{\prime} \mathrm{N}$ Lat, $13^{\circ} 14^{\prime} \mathrm{E}$ Long), Kr. Marienberg. Found 1896 in peat cutting, $1.75 \mathrm{~m}$ depth below surface. Dating unknown; suggested age on basis of pollen-analysis by Firbas was from Bronze age to modern. Yoke is kept in Mus. Marienberg/Erzgebirge. Subm. 1963 by W. Jacobeit, Inst. f. Volkskunde der DAW, Berlin (Tackenberg, 1939). Comment: medieval dating eliminates a supposed prehistoric age of the yoke.

\section{Bln-342. Serrahn}

$4166 \pm 120$ 2216 B.C.

Charcoal (Quercus sessiliflora) from Megalithic grave at Serrahn (53 $38^{\prime} \mathrm{N}$ Lat, $12^{\circ} 22^{\prime}$ E Long), Kr. Güstrow. Sample, dispersed between skeletal remains, was taken from a 20-cm-thick loamy layer on floor of enlarged dolmen, ca. $1.10 \mathrm{~m}$ below tumulus-surface. Burial was secondary and belonged to Globular Amphorae culture. Coll. 1964 and subm. by E. Schuldt, Mus. f. Vor- u. Frühgeschichte, Schwerin. Comment: date is acceptable compared to dates of late Funnel Beaker culture and Corded ware.

\section{Bln-162. Tornow}

$$
1125 \pm 100
$$

Grain (Secale cereale L.) from an early medieval fortification (Burgwall) at Tornow $\left(51^{\circ} 31^{\prime} \mathrm{N}\right.$ Lat, $13^{\circ} 50^{\prime} \mathrm{E}$ Long), Kr. Calau. Taken from a wooden box at Granary 3 in second fortification (B), ca. $2.80 \mathrm{~m}$ below top of wall. Assigned to Old Slavic period (beginning of 9th century). Coll. 1962 and subm. by J. Herrmann, Inst. f. Vor- u. Frühgesch. d. DAW, Berlin (Herrmann, 1966). Comment: in agreement with archaeological dating of the Tornow group. 


\section{Bln-164. Wüste Kunersdorf}

$$
2138 \pm 80
$$

188 B.c.

Charcoal (Quercus sessiliflora) from settlement of Younger Bronze age, Late Iron period and Roman Empire time at Wüste Kunersdorf (52 $24^{\prime} \mathrm{N}$ Lat, $14^{\circ} 31^{\prime} \mathrm{E}$ Long), Kr. Seelow. Taken from culture layer in Sector E 102, $0.80 \mathrm{~m}$ below surface. Assigned to Late Iron age (Vorrömische Eisenzeit). Coll. 1962 and subm. by R. Laser, Inst. f. Ur- u. Frühgesch. d. Humboldt-Univ., Berlin (Seyer, 1962) .

\section{Tell Azmak series}

\section{B. Bulgaria}

Tell of Azmak is $6 \mathrm{~km} \mathrm{E}$ of Stara Zagora $\left(42^{\circ} 27^{\prime} \mathrm{N}\right.$ Lat, $25^{\circ} 46^{\prime} \mathrm{E}$ Long), in southern Bulgaria. Excavations of the whole prehistoric mound between 1960 and 1963 were directed by G. I. Georgiev of Archaeol. Inst. of Bulgarian Acad. of Sciences in Sofia. The mound, with diam of $80 \mathrm{~m}$ and height of $7.94 \mathrm{~m}$ above marsh level, gave stratigraphic succession from Neolithic to Early Bronze age. Cultural layers were accumulated up to thickness of $7.5 \mathrm{~m}$, of which $3 \mathrm{~m}$ belonged to Neolithic and $4.5 \mathrm{~m}$ to Eneolithic and Bronze age. In Neolithic period five dwelling horizons of Karanovo I culture and a much destroyed sixth level of Karanovo III were observed. After a break, Eneolithic occupation accumulated ca. $3.80 \mathrm{~m}$ with eight dwelling horizons; lower four belong to Karanovo V and top four to Karanovo VI culture (Georgiev, 1965). Most charcoal samples were burned wooden posts or carbonized grain and seeds from ovens, storage vessels, and pits. Coll. and subm. by G. I. Georgiev, Sofia.

In the following list depths are stated in heights above level of Azmak Lake. All samples with exception of Bln-134 and 135 were coll. in eastern part of mound. Grid references are to areas of $5 \times 5 \mathrm{~m}$.

\section{Bln-291. Karanovo I culture: I-1 5208 B.c.}

Charcoal sample 1/64 (Quercus sp.) from Area 84-b in Level I-1, 1.13 m high. Coll. July 10, 1962.

\section{B》n-292. Karanovo I culture: I-I}

Grain sample 2/64 (Triticum dicoccum, T. monococcum) from Area 84-a in Level I-I, 0.96 m high. Coll. Aug. 22, 1962.

\section{Bln-293. Karanovo I culture: I-I}

$7303 \pm 150$

Charcoal sample 3/64 (Quercus sp.) from Area 85-w in Level I-1, $0.66 \mathrm{~m}$ high. Coll. Aug. 18, 1962.

\section{Bln-294. Karanovo I culture: I-I}

Charcoal sample 4/64 (Quercus sp.) from Area 85-w in level I-1, 0.66 m high. Coll. Aug. 20, 1962. 
BIn-296. Karanovo I culture: I-2

Charcoal sample 6/64 (Quercus sp.) from Area 99-b in Level I-2, $1.40 \mathrm{~m}$ high. Coll. July 30, 1962.

\section{Bln-295. Karanovo I culture: I-2}

$6720 \pm 100$

Grain sample 5/64 (Triticum dicoccum, T. aestivum L., sens. lat.) from Area 83-w in Level I-2, $1.11 \mathrm{~m}$ high. Coll. Oct. 9, 1962.

\section{Bln-299. Karanovo I culture: I-3}

$6812 \pm 100$

Charcoal sample 9/64 (Fraxinus cf. ornus L.) from Area 99-b in Level I-3, $1.69 \mathrm{~m}$ high. Coll. July 24, 1962.

\section{Bln-297. Karanovo I culture: I-3}

$6675 \pm 100$

Grain sample $7 / 64$ (Triticum dicoccum, T. aestivum L., sens lat.) from Area 100-a in Level I-3, 2.16 m high. Coll. Aug. 10, 1962.

\section{Bln-298. Karanovo I culture: I-3}

$6540 \pm 100$

Charcoal sample 8/64 (Quercus sp.) from Area 100-a in Level I-3, $2.16 \mathrm{~m}$ high. Coll. Aug. 10, 1962.

\section{BIn-301. Karanovo I culture: I-4}

$6483 \pm 100$

4533 в.c.

Charcoal sample 11/64 (Quercus sp.) from Area 70-g in Level I-4, $2.41 \mathrm{~m}$ high. Coll. July 11, 1962.

\section{Bln-300. Karanovo I culture: I-4}

$6426 \pm 150$

Charcoal sample 10/64 (Quercus sp.) from Area 132-b in Level I-4, $2.14 \mathrm{~m}$ high. Coll. July 27, 1962.

\section{Bln-430. Karanovo I culture: I-5}

$6279 \pm 120$

4329 B.c.

Seed sample 10/65 (Lathyrus cf. cicera L., Vicia cf. angustifolia L., Pisum sp.) from Area 85-a in Level I-5, 2.24 m high. Coll. May 14, 1962.

\section{Bln-203. Karanovo I culture}

$6880 \pm 100$

Charcoal (Quercus cf. pubesceus Willd.) from burned layer at eastern side of central profile, $1.88 \mathrm{~m}$ high. Coll. June 19, 1963 and subm. by H. Quitta.

\section{BIn-267. Karanovo I culture}

$6758 \pm 100$

Powdered charcoal (unidentifiable) with same position as Bln-203.

\section{Bln-224. Karanovo I culture}

$6652 \pm 150$

4702 B.C.

Charcoal (Quercus sp.) from same profile, probably Level I-4, 2.18 m high. Coll. June 13, 1963 and subm. by H. Quitta. 
Bln-136. Karanovo $V$ culture: III-2

Charcoal sample 6/62 (Quercus sp.) from Area 84-a in Level III-2, $4.20 \mathrm{~m}$ high. Coll. Oct. 11, 1961.

Bln-143. Karanovo V culture: III-2

$5737 \pm 150$

3787 B.c.

Seed sample 13/62 (Vicia cf. angustifolia) from Area 70-w in Level III-2, $3.80 \mathrm{~m}$ high. Coll. Oct. 30, 1961.

\section{Bln-150. Karanovo $V$ culture: III-2}

$5630 \pm 150$

Grain sample 20/62 (Hordeum vulgare L., subsp. polystichum var. nudum) from Area 83-g in Level III-2, 4.20 m high. Coll. Oct. 13, 1961.

\section{Bln-151. Karanovo V culture: III-3}

$5829 \pm 100$

3879 B.c.

Seed sample 21/62 (Vicia cf. augustifolia, Hordeum vulgare, polystichum var. nudum, Lens cf. esculenta Moench) from Area 69-g in Level III-3, $3.60 \mathrm{~m}$ high. Coll. Oct. 11, 1961.

Bln-148. Karanovo V culture: III-3

$5760 \pm 150$

3810 B.c.

Seed sample 18/62 with same species and same positions as Bln-151.

\section{Bln-142. Karanovo $V$ culture: III-4}

$5803 \pm 150$

3853 в.c.

Grain sample 12/62 (Hordeum vulgare polystichum var. nudum, Lens cf. esculenta) from Area 84-a in Level III-4, $4.70 \mathrm{~m}$ high. Coll. Aug. 15,1961 .

Bln-137. Karanovo V culture: III-4

$5697 \pm 100$ 3747 B.c.

Charcoal sample 7/62 (Quercus sp.) from Area 115-w in Level III-4, $5.30 \mathrm{~m}$ high. Coll. July 31, 1961.

\section{Bln-147. Karanovo V culture: III-4}

$5219 \pm 150$ 3269 B.c.

Grain sample 17/62 (Hordeum vulgare polystichum var. nudum) from Area 97-w in Level III-4, $4.35 \mathrm{~m}$ high. Coll. Nov. 14, 1961.

\section{Bln-149. Karanovo VI culture: IV-1}

$5888 \pm 100$

3938 B.c.

Grain sample 19/62 (Hordeum vulgare polystichum var. nudum, Triticum monococcum, Pisum cf. elatius Stev) from Area 84-w in Level IV-1, $4.00 \mathrm{~m}$ high. Coll. Aug. 31, 1961.

\section{BIn-145. Karanovo VI culture: IV-1}

$5390 \pm 100$

Seed sample 15/62 (Lens cf. esculenta, Vicia cf. angustifolia, Hordeum vulgare polystichum var. nudum) from Area 116-b in Level VI-1, $5.70 \mathrm{~m}$ high. Coll. July 8, 1961. 
Bln-146. Karanovo VI culture: IV-1

$5035 \pm 150$ Grain sample 16/62 (Hordeum vulgare polystichum var. nudum) from Area 84-w in Level VI-1, $5.60 \mathrm{~m}$ high. Coll. July 11, 1961.

\section{BIn-131. Karanovo VI culture: IV-2}

Charcoal sample 1/62 (Viburnum sp., Carpinus sp., Ulmus sp.) from Area 99-b in Level IV-2, $6.21 \mathrm{~m}$ high. Coll. Aug. 11, 1960.

\section{BIn-139. Karanovo VI culture: IV-2}

$5703 \pm 100$

Seed sample 9/62 (Vicia cf. angustifolia) from Area 83-g in Level IV-2, $6.04 \mathrm{~m}$ high. Coll. Aug. 11, 1960.

\section{Bln-144. Karanovo VI culture: IV-2}

$5597 \pm 120$

Seed sample 14/62 with same species and same positions as Bln-139.

\section{Bln-135. Karanovo VI culture: IV-3}

$5700 \pm 100$

\section{Bh-135. Karanovo VI culture: IV.3} in Level IV-3, $6.00 \mathrm{~m}$ high. Coll. Aug. 8, 1960.

\section{Bln-138. Karanovo VI culture: IV-3}

$5621 \pm 200$

Charcoal sample 8/62 (Ulmus sp.) from Area 115-a in Level IV-3, $6.81 \mathrm{~m}$ high. Coll. July 11, 1960.

\section{Bln-141. Karanovo VI culture: IV-3}

$5620 \pm 100$

Grain sample 11/62 (Triticum monococcum, T. dicoccum) from Area 84-b in Level IV-3, $5.90 \mathrm{~m}$ high. Coll. Aug. 10, 1960.

\section{Bln-134. Karanovo VI culture: IV-3}

Charcoal sample 4/62 (Quercus sp.) from Area 98-b (western part) in Level IV-3, 6.21 m high. Coll. Apr. 19, 1960.

General Comment: $\mathrm{C}^{14}$ measurements of Azmak levels for the most part agree with cultural sequence and archaeological interpretation (see table, fig. 1). Averages are best calculated from grand total of $\mathrm{C}^{14}$ counts of dwelling levels from Karanovo I culture, as follows: Level I-5, 4329 B.c.; Level I-4, 4522 в.C.; Level I-3, 4696 в.c.; Level I-2, 4794 в.c.; and Level I-1, 4932 B.c.

Dates for Bln-293 and Bln-291 appear to be too old, but may mean that oak timber used for house construction was sometimes much older than age of settlement. The proven break in continuity of occupation of Azmak mound after the Karanovo III layer coincides with the big time gap between Neolithic and Eneolithic dates. Average of all eight dates from Karanovo V culture is 3743 B.c., or 3810 B.c. without Bln-147, which seems to be too young. $\mathrm{C}^{14}$ dates of the Karanovo VI culture may seem 


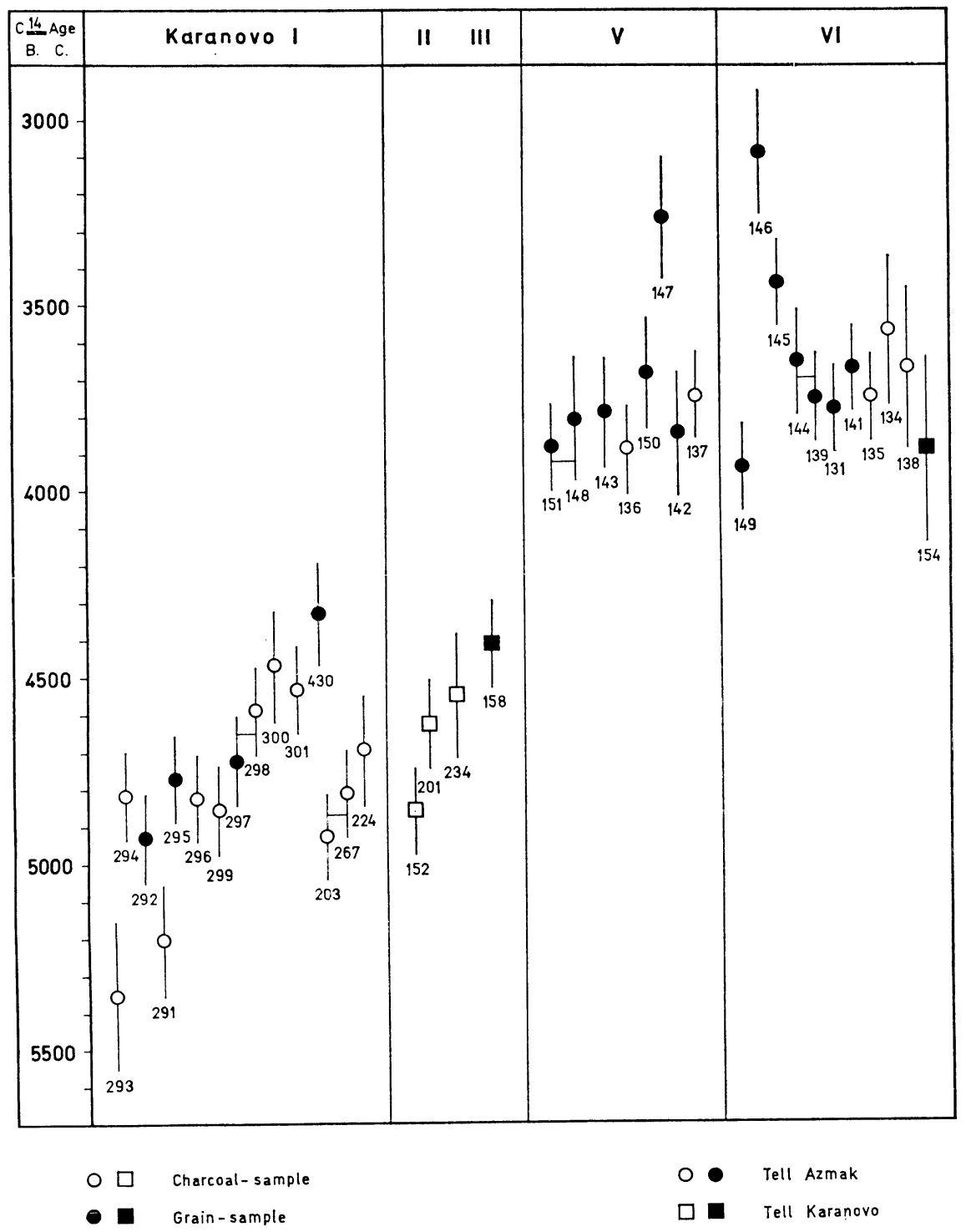

Fig. 1. $\mathrm{C}^{14}$ dates, arranged in stratigraphic order, at two early Neolithic sites in southern Bulgaria. 
surprisingly high; average of second dwelling level is 3732 в.c. and of third level 3664 в.c. However, equivalent measurements of late Karanovo culture from Chotnica (see Bln-125, this list) and other samples dated at Groningen (Groningen IV and V) from a middle phase of Gumelnita culture (GrN-1987, GrN-3025, GrN-3028) and the related Salcuţa group (GrN-1989, GrN-1990), as well as dates of Vinča-Pločnik (GrN-1974, GrN-1542), confirm the early $\mathrm{C}^{14}$ age of Balkan Eneolithic period. This is very complicated problem and we hope that new measurements of Early Bronze age (Karanovo VII) and similar cultures in the Danubian plain and in Anatolia will help to solve it. Some dates of the Azmak series do not fall in line with their stratigraphical position, but this may be caused by minor archaeological disagreement or by secondary contamination. No explanation can be given for great differences between three dates (Bln-145, 146, 149) of the first dwelling level from Karanovo VI culture.

\section{Tell Karanovo series}

Tell Karanovo is $9 \mathrm{~km} \mathrm{NW}$ of Nova Zagora $\left(42^{\circ} 30^{\prime} \mathrm{N}\right.$ Lat, $25^{\circ} 56^{\prime}$ E Long) in Southern Bulgaria. Excavations in four sectors between 1947 and 1957 were directed by V. Mikov and G. I. Georgiev of Archaeol. Inst. of the Bulgarian Acad. of Sciences in Sofia. The 12.40-m-high mound, 180 to $250 \mathrm{~m}$ in diam, is one of the largest in the Balkans. Profile indicates a complete cultural sequence from Neolithic (Karanovo I-IV) through Eneolithic (Karanovo V-VI) to Early Bronze age (Karanovo VII). A further distinction is possible on basis of building horizons, but is not elaborated here (Mikov, 1959; Georgiev, 1961).

\section{BIn-152. Karanovo II culture}

$6807 \pm 100$

Charcoal sample 22/62 (Quercus sp.) from Sector III in SW side of mound, Level II. Coll. June 19, 1949 and subm. by V. Mikov/G. I. Georgiev, Sofia.

\section{Bln-201. Karanovo II culture}

$6573 \pm 100$ Cherizon in northern profile of Sector III. Sample, associated with Karanovo II potsherds, was taken at $1.40 \mathrm{~m}$ above ground level. Coll. June 14, 1963 and subm. by H. Quitta.

\section{Bln-234. Karanovo II culture}

$6500 \pm 150$

Charcoal (Quercus cf. pubescens Willd.) from same building horizon as Bln-201, but taken from eastern profile of Sector III. Coll. June 14, 1963 and subm. by H. Quitta.

\section{Bln-158. Karanovo III culture}

$6360 \pm 100$

Grain sample 28/62 (Triticum dicoccum, T. monococcum, Hordeum vulgare var. nudum) from Sector IV in NE side of mound, Level 
III, $8.90 \mathrm{~m}$ below surface. Coll. Nov. 1954 and subm. by V. Mikov/G. I. Georgiev.

\section{Bln-154. Karanovo VI culture \\ Bh-154. Karanovo VI culture}

Grain sample 24/62 (Triticum dicoccum, Hordeum vulgare polystichum var. nudum, Vicia cf. angustifolia) from Sector IV, taken from destroyed house in Level VI, $2.70 \mathrm{~m}$ below surface. Coll. Oct. 10, 1949 and subm. by V. Mikov/G. I. Georgiev.

General Comment: Bln-154 is older than expected age for end of Karanovo VI culture. Other dates of Karanovo II and III seem acceptable in comparison with Azmak dates.

\section{Bln-125. Chotnica \\ $5560 \pm 100$}

Grain (Triticum dicoccum, T. monococcum) from upper dwelling horizon of Tell Chotnica (43 $8^{\prime} \mathrm{N}$ Lat, $25^{\circ} 28^{\prime} \mathrm{E}$ Long), district Tarnovo. Taken in western part of mound, $5 \mathrm{~m}$ high, from burned layer of House 2, $0.90 \mathrm{~m}$ below surface. Belongs to late Eneolithic period (Karanovo VI). Coll. 1956 and subm. by N. Angelov, Arch. Mus. Tarnovo (Angelov, 1958). Comment: agrees with dates of same period in Bulgaria and also with dates of related Gumelnita culture in Romania.

\section{Bln-202. Kapitan Dimitrievo 2292 B.c. \\ Bln-405. 2125 в.c.}

Grain (Triticum dicoccum, T. monococcum) from the Tell "Banjata," $1.5 \mathrm{~km} \mathrm{~W}$ of Kapitan Dimitrievo $\left(42^{\circ} 5^{\prime} \mathrm{N}\right.$ Lat, $24^{\circ} 22^{\prime} \mathrm{E}$ Long), district Pasardžik in southern Bulgaria. Taken from destroyed dwelling horizon $6 \mathrm{~m}$ below surface; mound was $12 \mathrm{~m}$ high. Assigned on basis of Kapitan Dimitrievo sequence to Eneolithic period (Karanovo V/VI). Excavated 1947 and subm. by P. Detev, Arch. Mus. Plovdiv (Detev, 1950; Georgiev, 1961). Comment: neither date agrees with $\mathrm{C}^{14}$ age of other Karanovo V and VI sites. As top level of Banjata mound represents remains of Early Bronze age, it seems possible that grain belonged to later period.

\section{Czechoslovakia}

\section{Bln-239. Tušimice}

$4768 \pm 100$

2818 B.C.

Charcoal (Pirus sp.) from Neolithic flint mine at Tušimice $\left(50^{\circ} 23^{\prime}\right.$ N Lat, $13^{\circ} 21^{\prime}$ E Long), Kr. Teplice, from Fireplace No. 1 on bottom of vertical pit, cut to $3.50 \mathrm{~m}$ depth in sandstone. Archaeological assignment unknown; no sherds in association with object. Only a few hammerstones and artifacts of quartzite and bone were found in the fill. Surface finds of Bandkeramik and TRB culture (probable Řivnač group). Coll. 
1962 and subm. by E. Neustupný, Archeol. ústav ČSAV-Expositur Most (Neustupný, 1963). Comment: evidently dates mining activity in the Eneolithic period.

\section{Bln-240. Žalany}

$5881 \pm 100$

3931 B.c.

Charcoal (Quercus sp.) of Bandkeramik dwelling site at Žalany ( $50^{\circ}$ $35^{\prime} \mathrm{N}$ Lat, $30^{\circ} 54^{\prime} \mathrm{E}$ Long), Kr. Teplice; from Dwelling Pit No. 1, dug to $0.90 \mathrm{~m}$ depth below surface in loess loam and overlain by humus soil $40 \mathrm{~cm}$ thick. Assigned to early phase of Stichbandkeramik. Excavated 1958 by N. Mašek, Town Mus. Prag; subm. by E. Neustupný, Arch. ústav C̆SAV-Expositur Most. Comment: Bln-240 agrees with dates of Zwenkau-Harth (Bln-66, $5900 \pm 100 ; \mathrm{K}-555,5840 \pm 120 ; \mathrm{H}-224 / 223$, $6000 \pm 115$; see Berlin I), belonging to same phase of Stichbandkeramik.

\section{Hungary \\ Bln-404. Szamossályi \\ $6136 \pm 100$ \\ 4186 B.C.}

Charcoal (Fraxinus cf. excelsior L.) from dwelling pit of Neolithic

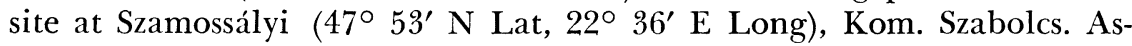
signed to local group of Linear pottery of NE Hungary. Coll. 1963 and subm. by J. Korek, Hungar. Nat. Mus. Budapest. Comment: no signifi-

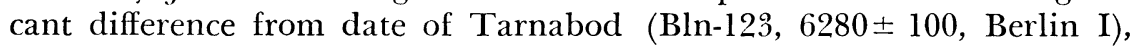
also belonging to Alföld group of Linear pottery.

\section{GEOLOGIC SAMPLES}

\section{A. The Lusitian ice-marginal valley}

History of the Lusitian ice-marginal valley (LIMV)-Breslau-Magdeburg-is shown by important sections in brown coal opencasts near Cottbus ( $\left.51^{\circ} 31.0^{\prime} \mathrm{N} \mathrm{Lat}, 14^{\circ} 7.2^{\prime} \mathrm{E} \mathrm{Long}\right)$. The LIMV, containing layers of peat and limnic sediments, was assigned to end of Warthe (pre-last) glacial epoch by Firbas and Grahmann (1928). Geological facts (Cepek, 1965) and $\mathrm{C}^{14}$ dates now transfer it to early Weichsel (last) glacial epoch. Brörup and Paudorf interstadials are represented in limnic-fluviatile facies. As soon as Brandenburg stage had attained its maximum extension during last glaciation, Spree River finished its break through Lusitian frontier wall and stopped sedimentation in the LIMV. Thus $\mathrm{C}^{14}$ dating permits an indirect age determination for maximum extent of last glaciation in Central Europe. Date, ca. 20,000 B.P., is in accord with ground moraines of Main Wisconsin, the maximum extent of last inland ice in North American region of glaciation, which was obtained by direct $\mathrm{C}^{14}$ dating. Table I summarizes the results (A.G.C.). All samples of LIMV are coll. and subm. by A. G. Cepek, Zentrales Geologisches Institut der VVB Feste Minerale, Berlin N 4, Invalidenstrasse 44. 
TABLE 1

Arrangement of the Weichsel glaciation by Radiocarbon Dates

\begin{tabular}{lcll}
\hline \multicolumn{1}{c}{ Found in the LIMV } & C14 age B.P. & NE German arrangement* \\
\cline { 1 - 2 } Niemtsch; & 11,000 & younger Dryas \\
Marga & 11,130 & Alleröd \\
& & older Dryas \\
& & Bölling \\
& & Pommeranian \\
Klein-Koschen, Skado & 20,270 & & Blankenburg \\
& 21,160 & & Brandenburg \\
Marga D; Skado; Lohsa & $\{25,670\}$ & & Paudorf \\
Marga C & $26,440\}$ & & \\
Marga B; Skado & 30,415 & & Brörup \\
Marga A ? & $>40,000$ & Amersfort \\
& & Eem \\
\hline
\end{tabular}

* Arranged by A. G. Cepek, 1958.

\section{Skado series, Lusitian ice-marginal valley}

Samples from brown-coal open cast Skado near Sorno/Hoyerswerda, Bez. Cottbus (51 $31^{\prime} \mathrm{N}$ Lat, $14^{\circ} 7.2^{\prime} \mathrm{E}$ Long).

\section{Bln-99. Skado, No. 8 (59)}

$9905 \pm 200$

7955 B.c.

Moss-peat, depth $7 \mathrm{~m}$ at base of an $0.9 \mathrm{~m}$ thick peat layer under sand. Pollen date, Preboreal (v. Bülow, 1926). Coll. 1959.

Bln-100. Skado, No. 2 (59)

$21,825 \pm 600$ 19,875 B.C.

Muddy silt with peat, depth 10 to $11 \mathrm{~m}$. Assigned to late Würmglacial by Firbas and Grahmann. Coll. 1959.

Bln-104. Skado, No. 3 (59)

$30,415 \pm 700$

Peat, depth $8 \mathrm{~m}$.

Bln-108. Skado, No. 7 (59)

$>40,000$

Muddy peat, depth 4.6 to $4.7 \mathrm{~m}$. Late Warthe glacial, according to Firbas and Grahmann.

Bln-109. Skado, No. 6 (59)

Muddy peat, depth 5.3 to $5.4 \mathrm{~m}$. Late Warthe glacial, according to Firbas and Grahmann. 
Bln-110. Skado, No. 5 (59)

$25,670 \pm 600$

(o 3.0 to $3.2 \mathrm{~m}$. Late Warthe glacial, according to Firbas and Grahmann. Comment (A.G.C.): late Paudorf interstadial.

Bln-111. Skado, No. 4 (59)

$22,110 \pm 400$

20,160 в.c.

Organic silt, depth 3.5 to $3.7 \mathrm{~m}$. Late Warthe glacial, according to Firbas and Grahmann. Comment (A.G.G.): late Paudorf interstadial.

Bln-222. Skado, No. 2 (64)

$>40,000$

Lower Tropfenboden (mud with coarse organic detritus), depth 7.1 to $7.3 \mathrm{~m}$. Comment (A.G.C.): Brörup interstadial.

Bln-362. Skado, No. 1 (64)

$15,900 \pm 650$

Upper Tropfenboden (fine-sandy, slightly organic silt), depth 1.5 to $1.6 \mathrm{~m}$.

Bln-363. Skado, No. 3 (64)

$20,475 \pm 600$ 18,525 в.c.

Fine-sandy silt with plant remains, depth 3.0 to $3.1 \mathrm{~m}$, post-Paudorf (A.G.C.).

Bln-364. Skado, No. 4 (64)

$19,310 \pm 1000$

Fine-sandy silt with plant remains, depth 2.10 to $2.15 \mathrm{~m}$.

\section{Lohsa series}

Samples from brown-coal open cast "Glück auf III" near Lohsa/ Hoyerswerda, Bez. Cottbus ( $51^{\circ} 23.2^{\prime} \mathrm{N}$ Lat, $14^{\circ} 26.0^{\prime} \mathrm{E}$ Long). The importance of the Lohsa profile is its position near the $S$ end of L.I.M.V. The overlying sands were spread as a sandr, outward from the bank of the Spree. Samples from measured section, as follows:

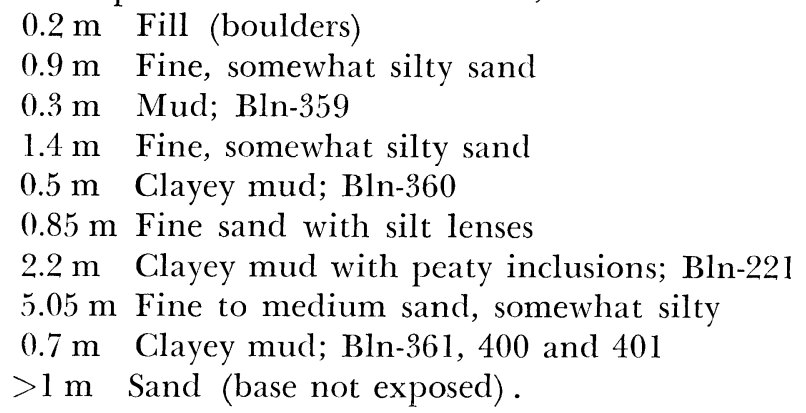

Bln-359. Lohsa III No. 1

Mud (filled whirlpool, Kolkfüllung), depth 1.2 to $1.3 \mathrm{~m}$. Comment: according to pollen analysis (K. Erd) sample corresponds roughly to late Slavic time (ca. A.D. 1000). 
Bln-360. Lohsa III No. 2

Clayey mud, slightly organic, depth 3.0 to $3.2 \mathrm{~m}$. Comment: cryoturbation has disturbed the layers of sand and silt within and under the sandr ( 1 to $2 \mathrm{~m}$ thick) of the Spree. Pollen is dominantly NAP (95\%), mainly grass and sedge. Sampled layer of clayey mud shows diminishing AP (Pinus, some Betula), and is assigned to the Paudorf interstadial (A.G.C.).

Bln-221. Lohsa III No. 3

$\mathbf{2 6 , 4 4 0} \pm \mathbf{8 0 0}$

Peat lens in clayey mud, depth 5.8 to $5.9 \mathrm{~m}$.

Bln-361. Lohsa III No. 4

Bln-400.

$\mathbf{3 3 , 1 0 5} \pm \mathbf{5 0 0 0}$

Bln-401. $>40,000$

Clayey mud, depth 11.7 to $11.8 \mathrm{~m}$. Samples Bln-361 and 400 had $\mathrm{HCl}$ pretreatment only; $\mathrm{Bln}-401$ had $\mathrm{HCl}$ and $\mathrm{NaOH}$ treatment, to remove humic acid. Comment (A.G.C.): horizon corresponds to Brörup interstadial of Skado. Clayey mud has only 20 to $30 \% \mathrm{NAP}$ and is dominated by Pinus and Betula. All thermophiles (Abies, Picea, Carpinus and Corylus) are below $1 \%$.

\section{Niemtsch series}

Samples from brown-coal open cast Niemtsch $\left(51^{\circ} 30.7^{\prime} \mathrm{N}\right.$ Lat, $14^{\circ}$ 3.4' E Long), Kreis Senftenberg, Bez. Cottbus. Sampled 1964 from measured section, as follows:

$0.7 \mathrm{~m}$ Mud of "Schwarze Elster" river

$0.7 \mathrm{~m}$ Sand

$0.1 \mathrm{~m}$ Peat (Holocene?); Bln-375

$4.9 \mathrm{~m}$ Sand, gravelly

$0.4 \mathrm{~m}$ Mud, frost-contorted; Bln-376, "Tropfenboden"

$8.0 \mathrm{~m}$ Sand, gravelly.

Bln-375. Niemtsch, 1964

$12,000 \pm 640$

Peat.

Bln-376. Niemtsch, 1964

$>36,000$

Tropfenboden, depth 6.5 to $6.7 \mathrm{~m}$.

Bln-127a. Niemtsch, 1962

$11,130 \pm 200$

9180 B.c.

Peat, from middle of layer, AP ca. 70 to $80 \%$ (85\% Pinus, $10 \%$ Betula, 1 to $2 \%$ Picea).

Bln-127. Niemtsch, 1962

$11,440 \pm 200$

Wood, near basal peat.

9490 B.c. 


\section{Bln-128. Niemtsch, 1962}

Muddy peat, ca. $80 \%$ AP (Pinus equals Betula, some Salix; K. Erd). 1962 section was as follows:
$0.9 \mathrm{~m}$ Mud of "Schwarze Elster"
$1.6 \mathrm{~m}$ Sand
$0.15 \mathrm{~m}$ Muddy peat
$1.35 \mathrm{~m}$ Fine sand with mud layers
$0.4 \mathrm{~m}$ Peat; Bln-127, 127a and 128 .

Comment: this series of Alleröd dates corresponds well to the pollen analysis (made by K. Erd) .

\section{Bln-101. Kerkwitz No. 1 \\ $27,200 \pm 600$ \\ BIn-101a. 25,250 B.C. \\ $27,800 \pm 600$}

Fine detritus gyttja from Kerkwitz clay pit, Kr. Guben, Bez. Cottbus (53 $54.9^{\prime} \mathrm{N}$ Lat, $14^{\circ} 37.5^{\prime}$ E Long). Depth: 2.0 to $2.2 \mathrm{~m}$. Section: $1 \mathrm{~m}$, medium sand; $1 \mathrm{~m}$, clay, sandy; $0.2 \mathrm{~m}$, fine-detritus gyttja (Bln-101, 101a); $0.2 \mathrm{~m}$, diatom mud and gyttja; $1.7 \mathrm{~m}$, clay. Coll. 1959 and subm. by A. G. Cepek (Cepek, 1960). Comment: assigned to the late Eem interglacial on the basis of pollen analysis by K. Erd (1961), the layer now seems to belong to the Paudorf interstadial.

\section{Bln-126. Klein-Koschen}

$\mathbf{2 1 , 1 6 0} \pm \mathbf{8 0 0}$

Silt with some wood, carbonate-free, from brown-coal open cast Klein-Koschen, Kr. Senftenberg, Bez. Cottbus $\left(50^{\circ} 30.9^{\prime} \mathrm{N}\right.$ Lat, $14^{\circ} 5^{\prime} \mathrm{E}$ Long). Section, beginning 2.3 to $2.4 \mathrm{~m}$ below ground level: 1.5 to $2 \mathrm{~m}$, fine sand; ca. $1 \mathrm{~m}$, silt (sampled layer); $10 \mathrm{~m}$, sand. Comment: late Warthe glacial, according to Firbas and Grahmann; see Skado series, this date list.

\section{B. Other samples}

\section{Bln-368. Stubbenkammer I \\ Bln-369. \\ $39,700 \pm 3000$ \\ $>40,000$}

Fine-sandy humic silt, carbonate-free, from layer $0.2 \mathrm{~m}$ thick, overlain by 0.3 to $0.4 \mathrm{~m}$ of chalk, underlain by fine sand, $3.2 \mathrm{~m}$ thick, then by boulder clay; exposed in Baltic Sea cliff Stubbenkammer, $\mathrm{N}$ of Sassnitz, Kr. Rügen, Bez. Rostock ( $54^{\circ} 32.2^{\prime}$ N Lat, $13^{\circ} 40.9^{\prime}$ E Long). Pollen analysis (K. Erd) indicates a very cool climate; silt layer assigned to Holstein or Eem interglacial.

\section{Bln-365. Bansin No. 1}

$$
\begin{aligned}
11,267 & \pm 400 \\
9317 & \text { B.c. } \\
11,244 & >640 \\
\mathbf{9 2 9 4} \text { B.c. } &
\end{aligned}
$$

Bln-367. Bansin No. 3

Peat, frost-contorted and mixed with fine sand, from inactive cliff $0.75 \mathrm{~km} \mathrm{~N}$ of Bansin, Kr. Wolgast/Rostock (53 $58.9^{\prime} \mathrm{N}$ Lat, $14^{\circ} 8.2^{\prime} \mathrm{E}$ 
Long); from layer $0.7 \mathrm{~m}$ thick, overlain by $6 \mathrm{~m}$ of sand containing boulders, in part containing roots of grass and beech; underlain by fine sand $1 \mathrm{~m}$ thick, then by moraine $4 \mathrm{~m}$ thick. Coll. and subm. 1964 by A. G. Cepek. Comment: assigned by Keilhack (1917) to the last interglacial, but pollen analysis by Hallik (Hallik and Ludwig, 1959) indicates Alleröd age, confirmed here. Date is important for genesis of the Baltic, for the locality was reached by active ice during Younger Dryas time, when the ice-margin is supposed (De Geer, 1954) to have stood at a line from Stockholm to Helsinki.

\section{Bln-214. Hiddensee, Salzwiese}

$$
1265 \pm 100
$$

A.D. 685

Wood (beech), overlain by gray marine sand, $1.4 \mathrm{~m}$ thick, and by rush (Juncus) peat, 0.25 to $0.4 \mathrm{~m}$ thick at marsh surface; part of layer containing wood and amber in small pieces, presumably driftwood; on island of Hiddensee, Kr. Bergen/Rügen, Bez. Rostock. Coll. and subm. 1963 by E. Fröde, Forschungsanst. Hiddensee, Kloster auf Hiddensee. Comment: modern island of Hiddensee was formed by fusion of two islands, Hiddensee and Gellen; sample dates the fusion.

\section{Bln-242. Alperstedt II}

$9467 \pm 250$

7517 B.C.

Organic sandy clay, 2.2 to $2.4 \mathrm{~m}$ depth, overlain by chalky Flachmoor peat, underlain by sandy clay, at Alperstedt, Bez. Erfurt. Pollen analysis, by E. Lange, shows, at bottom of layer, Pinus $45 \%$, Betula $54 \%$, Salix $1 \%$ (of tree pollen) NAP + spores $29 \%$, with trace of Ephedra; at top of layer, NAP + spores $=38 \%$, but Pinus rises to make $98 \%$ of AP, with Betula $1 \%$ and Salix 1\%. Coll. and subm. 1963 by E. Lange, Inst. f. Spezielle Botanik, Friedr.-Schiller Univ., Jena. Comment: dates beginning of Holocene in Thuringia.

Date lists:

REFERENCES

Berlin I Kohl and Quitta, 1964

Groningen IV Vogel and Waterbolk, 1963

Groningen V Vogel and Waterbolk, 1964

Amende, E., 1928, Eine bandkeramische Grabstätte bei Rehmsdorf: Mitteilungen der Geschichts- und Altertumsforschenden Gesellschaft des Osterlandes, v. 13, p. $185-201$.

Angelov, N., 1958, Selišna mogila pri s. Chotnica: Studia in honorem Acad. D. Dečev, Sofia, p. 389-403.

Baumann, W., Czerney, P., Fiedler, H. J., 1964, Archäologische und bodenkundliche Untersuchungen an einem bandkeramischen Siedlungsprofil bei Dresden-Prohlis: Arbeits- und Forschungsberichte zur sächsischen Bodendenkmalpflege, v. 13, p. 7-50.

Baumann, W., 1965, Siedlung der Bandkeramik in Kmehlen, Kr. Grossenhain: Ausgrabungen und Funde, v. 10, p. 63-66.

Billig, G., 1965, Der Siebenhügel bei Köttichau, Kr. Hohenmölsen: Jahresschrift für mitteldeutsche Vorgeschichte, v. 46, p. 77-132.

Bülow, K. v., 1926, Notiz über ein alluviales Torflager in der Grube Marga (Niederlausitz) : Zentralblatt für Mineralogie etc. Abh. B., p. 333.

Cepek, A. G., 1960, Eisrandlagen, Interglaciale und "Präglazial" in Brandenburg: Exkursionsführer Brandenburg. 7. Jahrestagung der Geolog. Ges. DDR, Berlin 1960 , p. $130-134$ 
1965, Geologische Ergebnisse der ersten Radiokarbondatierungen von Interstadialen im Lausitzer Urstromtal: Geologie, v. 14, p. 625-657.

Coblenz, W., 1951, Die Sumpfschanze von Brohna bei Bautzen: Arbeits- und Forschungsberichte zur sächsischen Bodendenkmalpflege, v. 1, p. 65-92.

Czerney, P., 1965, Bodenkundliche Untersuchungen einer fossilen und einer rezenten Schwarzerde: Albrecht Thaer-Archiv, v. 9, p. 867-881.

Detev, P., 1950, Selišnata mogila Banjata pri Kapitan Dimitrievo: Annuaire du Musée National Archéologique Plovdiv, v. 2, p. 1-21.

Erd, K., 1961, Das Eem-Interglazial von Kerkwitz-Atterwasch bei Guben: Wiss. Z. Pädagog. Hochschule Potsdam, math.-nat. Reihe 6.

Feustel, R., Gall, W., 1965, Urnenfelderzeitliche und frühmittelalterliche Siedlung bei Ichtershausen, Kr. Arnstadt: Ausgrabungen und Funde, v. 10, p. 230-231.

Firbas, F., Grahmann, R., 1928, Über jungdiluviale und alluviale Torflager in der Grube Marga bei Senftenberg: Abhandlungen math. phys. Klasse der Sächs. Akad. d. Wiss., v. 40.

Georgiev, G. I., 1961, Kulturgruppen der Jungstein- und Kupferzeit in der Ebene von Thrazien (Südbulgarien) : L'Europe à la fin de l'âge de la pierre, Prague, p. 45-100. p. $6-8$.

Godwin, H., 1962, Half-life of Radiocarbon: Nature, v. 195, p. 984.

Grössler, H., 1907, Das Fürstengrab im grossen Galgenhügel am Paulsschacht bei Helmsdorf: Jahresschrift für die Vorgeschichte der sächsisch-thüring. Länder, v. 6, p. $1-87$.

Hallik and Ludwig, 1959, Ein spätglaziales Torfprofil auf der Insel Usedom: Archiv der Freunde der Naturgeschichte Mecklenburgs, v. 5, p. 20-35.

Herrmann, J., 1966, Tornow und Vorberg, Berlin: Schriften der Sektion für Vor- und Frühgeschichte, v. 21.

Kohl, G. and Quitta, H., 1964, Berlin radiocarbon measurements I: Radiocarbon, v. 6 , p. $308-317$

Krüger, B., 1964, Eine altslawische Siedlung in Dessau-Mosigkau: Ausgrabungen und Funde, v. 9, p. 42-50.

Mikov, V., 1959, The prehistoric mound of Karanovo: Archaeology, v. 12, no. 2, p. 88-97.

Neustupný, E., 1963, Pravěké doly v Tušimicích: Památky-příroda-život, v. 3, Chomutov, p. $1-4$

Quitta, H., 1964, Zur Herkunft des frühen Neolithikums in Mitteleuropa: Varia archaeologica, Schriften der Sektion für Vor- und Frühgeschichte, v. 16, p. 14-24.

Seyer, H., 1962, Die Ausgrabungen der germanischen Siedlung bei Wüste Kunersdorf, Kr. Seelow: Ausgrabungen und Funde, v. 7, p. 117-119.

Tackenberg, K., 1939, Ein Doppeljoch aus dem Reitzenhainer Moor bei Annaberg/ Erzgebirge: Kultur und Rasse, Reche-Festschrift, Leipzig, p. 233.

Weber, V., 1964, Zwei weitere schnurkeramische Grabhügel aus dem Forst Leina, Kr. Altenburg: Arbeits- und Forschungsberichte zur sächsischen Bodendenkmalpflege, v. 13, p. 193-222. 